\title{
E-commerce Business Models for the Music Industry
}

\author{
Mark Fox
}

\section{Introduction}

In 2000, global sales of CDs, cassettes, and vinyl records amounted to approximately US\$37 billion (International Federation of the Phonograph Industry, "Recording"). The United States - the primary focus of this essay-is the world's largest music market, with at least \$12 billion in annual sales of recordings (Recording Industry Association of America, "Recording Industry Releases"). However, there are indications that recording sales have reached market saturation and may even be declining for some formats. Diebold, a leading German consulting group, has observed that global music sales fell from $\$ 41.5$ billion in 1995 to \$38.5 billion in 1999 (Diebold Group, “Wanted: A Survival Plan for the Music Industry-Chapter One" 1). Music sales in the United States dropped 2.6 percent in 2000, and sales of CD singles slumped by 36 percent (Recording Industry Association of America, "Recording Industry Releases"). According to the Recording Industry Association of America (RIAA), music product shipments between mid-2000 and mid-2001 decreased from $\$ 6.2$ billion to $\$ 5.9$ billion, a decline of 4.4 percent (RIAA, "The Cost of a CD" ).

Industry observers have attributed the decline in music sales to several factors, including a lack of "blockbuster" releases, competition from other media such as computer games for younger consumers, and the availability of free music on the Internet. By 2001, an estimated 30 million American adults-29 percent of all adults-had downloaded music files over the Internet (Graziano and Rainie 2). Younger Americans are even more likely to download music, with 53 percent of those between 12 and 17 years old (more than 7 million consumers) claiming to have downloaded music (Graziano and Rainie 2). Moreover, at least 79 percent of downloaders do not pay for the music they have retrieved from the Internet (Lenhart and Fox 2). The downloading of free music by young consumers is a particular concern for the music industry. Evidence indicates that these consumers are purchasing less music: Between 1991 and 2000, the overall market share declined from 18.1 percent to 12.9 percent for 15-19-year-olds, and from 17.9 percent to 12.9 percent for 20-24-year-olds (RIAA, "Recording Industry Association"). Understandably, these findings raise concerns about the future of music as a product, particularly with regard to young consumers, whose future music-purchasing habits are being influenced by the availability of free music over the Internet.

Offsetting these concerns are predictions that delivery of music over the Internet (i.e., music as a service) will expand significantly through 2005 (see Tables 1 and 2). Jupiter Media Metrix, an Internet market research firm, estimates that, in 2005, 76 million consumers will purchase $\$ 5.4$ billion of music online, thereby 
Table 1. Projected growth of online music, by Jupiter Media Metrix (US\$ millions).

\begin{tabular}{lccccc}
\hline & 2001 & 2002 & 2003 & 2004 & 2005 \\
\hline$\%$ of market online & 9.1 & 13.3 & 17.4 & 21.3 & 24.6 \\
Physical product & $\$ 1,431$ & $\$ 2,109$ & $\$ 2,713$ & $\$ 3,299$ & $\$ 3,853$ \\
Á la carte downloads & $\$ 34$ & $\$ 88$ & $\$ 189$ & $\$ 339$ & $\$ 531$ \\
Digital subscriptions & $\$ 5$ & $\$ 63$ & $\$ 278$ & $\$ 581$ & $\$ 980$ \\
Total online music spending & $\$ 1,469$ & $\$ 2,259$ & $\$ 3,181$ & $\$ 4,219$ & $\$ 5,364$ \\
\hline
\end{tabular}

Source: Jupiter Media Metrix (1).

Table 2. Projected growth of online music by Informa Media Group (US\$ millions).

\begin{tabular}{lrrrrr}
\hline & 2001 & 2002 & 2003 & 2004 & 2005 \\
\hline Traditional formats & 1,421 & 2,161 & 3,060 & 3,911 & 4,893 \\
Digital downloading & 22 & 86 & 258 & 584 & 989 \\
Subscriptions & 56 & 188 & 440 & 939 & 1,494 \\
Total online sales & 1,499 & 2,435 & 3,758 & 5,434 & 7,376 \\
\hline
\end{tabular}

Source: Informa Media Group (quoted in Pfahl 3).

accounting for approximately 25 percent of all music sales (1). Analysts at Jupiter Media Metrix anticipate that $\$ 3.9$ billion of these purchases will be comprised of physical items, typically CDs.

Aside from the sale of physical music products over the Internet, sales of music downloads may increase significantly over the next few years. Jupiter Media Metrix forecasts that a la carte downloads-where users download individual songs and pay a fee for each download-will increase from \$34 million in 2001 to $\$ 531$ million in 2005. However, most downloadable music sales are expected to take the form of subscriptions, wherein users pay a monthly fee to gain access to and download as many songs or albums as they choose. Jupiter Media Metrix predicts that digital subscriptions will amount to \$5 million in 2001 and increase to almost $\$ 1$ billion in 2005. By contrast, Informa Media Group suggests that a la carte downloads will increase from \$22 million in 2001 to almost $\$ 1$ billion in 2005, whereas subscriptions will increase from \$56 million in 2001 to around $\$ 1.5$ billion in 2005 (see Table 2).

Other estimates indicate a rapid increase in both a la carte and subscription music sales. Forrester Research posits that downloadable music sales will account for only $\$ 3$ million in sales in 2001, but will increase to more than $\$ 1$ billion in 2003 ("Dig" 1). Similarly, the Internet Underground Music Archive projects that revenues from digital distribution will exceed \$600 million in 2002 and reach $\$ 3.7$ billion in 2007 (Rothenberg 2). While these figures may be overly optimistic, the distribution of music as a service (rather than a physical product) likely will grow significantly in the future and will comprise an increasing proportion of overall music sales.

I propose that access to free music online has redistributed power in the music industry from music labels to individual consumers. The record labels have 
attempted to thwart the efforts of free music providers through the creation of copyright-protected files and through lawsuits against providers of free music. However, copy protection technologies to date have proved unsuccessful (Newton 1) and litigation has not halted the downloading of music files over the Internet. In any event, as Cary Sherman observes, "Litigation is not a business strategy. Ultimately the best response to online piracy is a legitimate alternative" (36). At present, record labels increasingly compete with free file-sharing systems for consumers. To compete effectively in this context, labels will need to price downloads in a way that recognizes the lower costs associated with providing music via the Internet. On a positive note, the same technology that makes it simple for music listeners to gain access to free music provides music labels with the opportunity to adopt new business models and thereby gain access to new revenue sources. Consumers will be willing to pay for such music only if they believe that they derive real value from doing so. In particular, the record labels will need to provide value over and above that provided by free music.

Clearly, the music industry faces considerable pressure to adopt new business models in order to meet consumer needs successfully in the e-commerce milieu. In particular-as is discussed in the following section-music labels are incurring lower costs and reduced barriers to entry. In the third section of this paper, I examine the business models that are being developed to respond to these changes and discuss the flaws inherent in these evolving business models. Napster's success indicates that consumers clearly value choice and convenience. To provide value to consumers, the major labels must cross-license their catalogs to third-party content aggregators (sites where consumers can gain access to a wide variety of music, from various labels).

\section{Reducing costs and barriers to entry}

The "Big Five" record labels (BMG Entertainment, Sony, AOL Time Warner, EMI, and Vivendi Universal Music Group) sell more than 80 percent of popular music (Coats et al. 287). Historically, the Big Five have effectively controlled most of the music supply chain (Hill 314). Also, contractual arrangements between record labels and artists have formed a major barrier to entry in the music industry. These arrangements, in essence, provide labels with monopoly rights to the artistic output of individual artists, from which the labels can then generate revenues. In particular, copyrights held by music labels comprise a key means to protect their economic assets-i.e., their investments in artistic talent (Sadler 1931). As Andrew Leyshon observes, "the ability to exploit copyright has been central to the profits of the music industry almost since its very inception" (52). Today, however, the revenue streams that accrue to those who control music copyrights are threatened by online music piracy.

Piracy - the unauthorized reproduction of copyrighted material-has always concerned the music industry. However, the effectiveness of industry associations such as the RIAA and IFPI (International Federation of the Phonograph Industry) in reducing piracy has been questioned. For example, Burke, in a multicountry study, found that international copyright conventions failed to reduce counterfeiting to comparatively low levels (51). With the advent of downloading technology, the music industry faces a new type of piracy: individuals who use Internet technology to infringe on copyrights held by the major record labels. Certainly, 
piracy is not new to the music industry; however, the advent of file compression technology-when combined with peer-to-peer networks such as Gnutella-has made it easier for consumers to engage in piracy. Consumer willingness to engage in piracy online increases as the likelihood of being observed becomes lower (few consumers would be willing to steal a compact disc from, say, Tower Records, yet millions downloaded mp3 files from Napster). Also, peer-to-peer networks allow consumers to access a much wider selection of music than has historically been the case with, for example, home taping. Finally, the cost of making CD-quality copies has declined with the diffusion of CD-recording technology. The IFPI observes that "Blank CD-R prices have plummeted with prices as low as \$0.15 to \$0.20 in some regions" ("2001" 3).

Aside from the barrier to entry traditionally posed by copyrights, the influence of the Big Five over the music industry has had several other consequences: (1) small record companies have difficulty surviving; (2) artists have had limited control over the distribution of their music; (3) high levels of industry concentration-i.e., the extent to which the major music labels dominate the industry, as measured by relative market share-have resulted in fewer releases of new recordings; and (4) consumers have had difficulty obtaining music without purchasing through approved channels, typically retailers or music clubs (Black and Greer 13-15; Cartwright 30; Rothenbuhler and Dimmick 143-44). With regard to distribution, the Big Five typically sell music directly to large retailers, or through large intermediaries to a vast array of local retailers (Coats et al. 287). Furthermore, the Big Five have substantial investments in existing distribution infrastructure (Alexander, "Product Variety" 208-09; Selby 4). As one online music company, Emusic.com, observes in its 1999 Annual Report:

Historically, the major record labels have been reluctant to participate in any alternative distribution model which would restructure the current music distribution hierarchy. [This reluctance is] due to their investment in the current physical distribution infrastructure and their relationship with the retail channel. (5)

Technological changes have heightened competition for the major labels. ${ }^{1}$ The distribution of music over the Internet requires only a single master copy, whereas distribution of music as a physical product requires producing, shipping, and warehousing CDs, audio cassettes, etc. When music is stored and sold as a computer file, disintermediation (the cutting out of middle layers of distribution channels) occurs. Disintermediation is particularly harmful to the Big Five, who, as Alexander ("Entry Barriers" 86-87, "Product Variety" 208-09) notes, are also major distributors to retail stores. Such economies of scale in the distribution of physical music products have historically placed smaller, independent music labels at a disadvantage (Alexander, "Product Variety" 208-209). In short, the Internet significantly reduces the Big Five's market power in the area of distribution. However, the major labels have faced similar competitive pressures deriving from such transformational technologies in the past. Indeed, new technologies such as CDs, which lowered production costs and the minimum efficient level of production, have played a role in fomenting significant new waves of entry into the music industry (Alexander, "Entry Barriers" 86). Although the major labels have weathered the introduction of new recording technologies in the past, they will need to take steps to retain their market dominance. Recent entrants, such as Freenet and Gnutella, that use downloading technology represent a formidable 
potential threat to the labels' control. These new rivals are not reliant upon existing industry infrastructure, particularly in the area of distribution, and also provide consumers with access to free music.

While new technology has threatened the Big Five's role in the area of distribution, these labels likely will retain certain spheres of influence, particularly in the areas of artist development, marketing, and promotion. The RIAA ("Cost of a $\mathrm{CD}^{\prime \prime}$ ) points to marketing and promotion costs as the most significant costs incurred in the music industry. Such expenditures are necessary to help artists stand out from competing releases. Whereas the major labels achieve significant economies of scale in promotion, small labels are hampered by, for example, the high costs associated with obtaining radio airtime. In an online world where consumers have many more listening choices, the role of promotion will become even more critical in differentiating individual artists and driving sales.

In short, downloadable music and its associated technologies have brought about a redistribution of power from major record companies to music consumers and, arguably, artists. In any event, digital technologies and the Internet have radically altered the value chain for the music industry in a number of ways that reduce costs and barriers to entry. Among other consequences, this shift provides many more opportunities for independent music labels to diminish the major labels' historical hegemony over traditional distribution methods. Independent music labels traditionally have provided an alternative means for artists to get their music to the marketplace. Owing to the high costs associated with promotion and distribution, however, independent labels rarely reach large audiences (Coats et al. 288). Furthermore, the independents historically have relied on the Big Five to distribute their products. However, attracting talent, a major problem for startup labels, has become somewhat easier owing to the cost reductions enabled by Internet distribution. Reduced overhead allows one such label, AtomicPop, to offer royalties in excess of 50 percent of revenues (Brull 2). The co-head of Matador Records has noted that "online distribution removes much of the power of the major labels, traditionally grounded in control of physical distribution and radio access" (quoted in Foege 162).

In addition to providing greater enticements for artists to sign with independent labels, digital technologies make the production and commercialization of music easier and less costly. May and Singer (129-30) propose that of the $\$ 15$ cost of a typical CD, electronic distribution would allow around $\$ 9$ to be "redistributed": $\$ 1$ in manufacturing costs, $\$ 1.40$ in distribution costs, $\$ 2.25$ in promotional dollars (as the Internet will allow for more targeted marketing), and $\$ 4$ of the retailer's markup. Hence, the lowered entry barriers that result from Internet delivery enable artists and intermediaries to undertake distribution and marketing activities more cheaply. Indeed, a key attraction of the Internet is that it permits practically anyone to distribute music, thereby undermining the control that major labels have historically had on the marketplace (Gerbert 3). Digital technology also has diminished the Big Five's hegemony over the production of music itself. Today, sophisticated production can be achieved on a computer: Individual musicians can create a sound equivalent to that produced under the auspices of the major labels. As Mia Garlick (6) suggests:

Lower production costs allow unsigned artists to compete with a label product in terms of quality and cost.... By reducing the initial investment, digital technologies reduce the risk of failure which in turn reduces the need for successful projects to subsidize the less successful. 
The perceived benefits of Internet-based music have impressed not only would-be artists and total neophytes (i.e., the average consumer), but established orchestras as well. Joseph Klueger, President of the Philadelphia Orchestra Association, observes that "it costs the same amount for the Philadelphia Orchestra to record Tchaikovsky whether you sell 50,000 units or 10,000 units. By using the Internet, we lower the breakeven point" (Salkever 2).

Additional issues relevant to the cost structure of music labels include cost savings associated with inventory control and better information on which to base decisions about investing in artists. As to the first issue, music labels presently need to forecast how many copies of a CD consumers will purchase. Inaccurate estimates can lead to over- or underproduction, a problem that does not occur in the digital distribution of music via the Internet (Fisher 2). Furthermore, downloadable music makes it easier for record companies in general, and smaller labels in particular, to compete without concerns about physical inventory. Online labels bypass the significant costs that major labels incur with regard to manufacturing, distribution, and retailer inventory-holding (Brull 2). LiquidAudio comments that "By eliminating inventory concerns we give every indie [independent] label and garage band the ability to make its music available for purchase" (quoted in Freund 1). With regard to the second issue, distributing music digitally enables labels to estimate better the likely success of artists whose careers they have chosen to promote. At present, as John Lovering observes, "investment is shaped by highly subjective corporate projections regarding future consumption patterns" (33). However, in an online environment, labels may predict individual consumer preferences more accurately, resulting in more informed decisions regarding which artists to develop so as to meet consumer needs. More exact estimates, in essence, lower artist and repertoire costs.

The preceding discusses how the forces presently at play may decrease costs and reduce barriers to entry in the music industry. The music industry may benefit greatly from the opportunities offered by Internet-based business models; however, the ease with which independent labels and new entrants (including artists themselves) can compete with the Big Five represents a significant concern for the music industry, as does the availability of free music. The next section of this article will discuss the business models that are emerging in response to the technological and social influences outlined above. The essay closes with some general conclusions and recommendations as to the benefits and factors required for the successful delivery of music as a service via the Internet.

\section{Business models}

The RIAA contends that free downloadable music, such as that provided through peer-to-peer services, undermines the Big Five's ability to sell digital music online. However, not all online distributors view music itself as the sole, or even the primary, source of revenue. In particular, so-called broadcasting models are being developed that enable consumers to obtain music for free, generating revenues from advertising, the sale of consumer data, and related products and services. In the next section, I discuss the ideology underlying these broadcasting models and provide some examples of their operation. Inevitably, business models in which music is a primary source of revenue are those that the music industry 
and, for that matter, musicians, most likely will adopt. Hence, I also examine the advantages and disadvantages of each of the three major business models that have emerged (namely the subscription, pay-per-track or pay-per-album, and artist-to-consumer models).

\section{Broadcasting model}

This model is analogous to television and radio broadcasting, in which consumers receive the content free while the broadcaster generates revenue through means such as advertising. This "broadcasting" model (also known as the free content or equity model) finds support with the so-called "open source" movement-those who believe that music should be free and call for new business models that better meet the needs of consumers in the digital age. Under this model, music represents a free service, a "loss leader," and revenues are generated from associated products and services (Glynn 2).

This model starts with the premise that the real value for music labels derives from the audience that consumes the music rather than from the product itself; the audience is the product that the labels deliver to the advertisers, and labels or artists realize value from consumers through advertising and data mining. The broadcasting model is also predicated on the belief that music has widespread social appeal and therefore significant potential for generating associated advertising revenues. Furthermore, the provision of music with advertising can have a major impact on marketers who wish both to monitor the effectiveness of their advertisements and to target consumers more accurately. As Sean Carton asks:

[W] hat if the consumption of that entertainment could be measured exactly in real time? Instead of relying on indirect measures to judge the effectiveness of our ads, or using indirect measures to find out about the audiences, we would be able to know exactly who is watching and/or listening, exactly what each person is watching and/or listening to, and when he/she is watching and/or listening. ... Instantly you have access to pinpoint user data that can then be used to market the stuff that people can't transmit across the Internet-the tangible hard goods-to the people waiting to buy them. (2)

Such a model could operate in several ways. First, music companies can provide, through each of their websites, music that visitors can listen to or download. These sites can generate revenue through advertising, sale of merchandise (such as t-shirts and posters), commissions on concert tickets, etc. Second, music labels could license their music for free distribution to third-party sites, which would then pay the labels a commission for its use. This model may hold more appeal for fans who could visit one site (rather than those of several music companies) to obtain much of the music they seek. The Diebold Group has proposed a third variation on the broadcasting model, in which users would access a marketing platform, provide information about themselves, and, in exchange, receive free access to music content. To continue their "free subscription," consumers would need to answer more questions each month. Data on consumer demographics and preferences could then be sold to advertisers and other interested parties (Diebold Group, Wanted).

One website that used the broadcasting model until recently is playj. Users visiting playj for the first time were prompted for personal information, including 
their interests and email addresses. Visitors subsequently could download or stream music for free. However, when this music was played, an advertisement from a "sponsor" appeared on the computer screen. The advertising targets individual consumers based on demographics, content, geography, and user behavior (EverAd). Furthermore, a real-time reporting system provided continual usage information to advertisers, who then could gauge the effectiveness of their promotional efforts. EverAd, the company that provided the play technology, shared the resultant advertising revenues with content providers and website affiliates. Free music models like playj are potentially attractive to digital music providers, owing to the relative youth of many fans. The RIAA reports that in 2000, 21.8 percent of music sales involved consumers aged nineteen or younger (RIAA, "Recording Industry Associations").

However, as Mia Garlick notes, the disadvantage of broadcasting models stems from the consumer's devaluing music: "This makes it harder for business models which charge to compete and arguably disincentivises artists from creating music" (6). Also, providing music for free jeopardizes critical ties with retailers and radio and outlets like MTVi, an online counterpart to MTV. Perhaps of greater concern, this model would entail a radical rethinking of how record labels deliver products. As Henry Mintzberg (176) comments, past strategy strongly influences current strategic choices. In this regard, the music industry operated with essentially the same business model for much of the twentieth century (Garofalo 323-29). In particular, control over distribution of physical products has long been central to industry performance. It is one thing for music executives to make the leap from music as a product to music as a service, but quite another for them to see sources of revenue lying predominantly outside the music itself. Unfortunately, this reluctance, coupled with the rank arrogance exhibited by many senior record company executives, appears to have played a role in the Big Five's laggard response to changing environmental forces. As Bruce Haring remarks in Beyond the Charts:

\footnotetext{
Record companies were slow to recognize the perils to their business spawned by the rise of the Internet. As late as 1998, many companies did not have staff whose job it was to monitor activities on the Net. Most senior executives, when they paid attention at all, dismissed the net as just another passing fad, the CB radio of the 1990s. Many executives privately felt that any changes that did develop would happen long after they were safely retired.

As such, the entrenched executives felt that supporting a new philosophy of distributing music, one which embraced a direct relationship with the consumer, was something that needed to be avoided at all costs. Their attitude amounted to a stone wall: we work for companies that have multinational reach and resources. We have the relationships. And more to the point, we have the artists under contract. We control the system. There is no need to change. (9-10)
}

Irrespective of these concerns, it is clear that music companies could still gain advertising revenue (or revenue-sharing arrangements) through licensing music for subscription or sale. Hence, the Big Five are extremely unlikely to adopt a broadcasting model.

\section{Subscription model}

Under a subscription model, consumers typically will pay a monthly fee to access a library of music. Estimates are that nearly 11 million online music fans are 
willing to pay a monthly subscription fee to download (legally) their favorite tunes (Hu 1). A study by Cyber Dialogue has found that 52 percent of respondents would pay for access to sites with downloading capabilities. Another survey, by MP3 Impact, reports that 27 percent of respondents would pay $\$ 25$ per month for access to a site offering digital downloads; 11 percent would pay $\$ 25$ to $\$ 50$ per month for such a service.

Consumers already have access to at least one such service-Emusic.com, which is owned by Vivendi Universal. For $\$ 9.99$ per month (if a user signs up for twelve months), Emusic offers subscribers access to more than 200,000 mp3 downloads. Emusic differs from services operated by the Big Five (as discussed below), because the music it offers results from licensing agreements with independent record labels.

Taking a contrasting approach, the Big Five introduced two major subscription services during 2001 and 2002: MusicNet and pressplay. MusicNet was launched by AOL Time Warner, BMG Entertainment, EMI, and RealNetworks, an Internet technology firm. The three major labels involved in MusicNet control 39 percent of music sales worldwide (Lee 1). MusicNet currently operates through RealOne Music (MusicNet). This service, like pressplay, will allow users to either download or stream music. Pressplay is a joint venture between Vivendi Universal and Sony, which have a combined market share of 45 percent. EMI has also licensed its music library to pressplay. The pressplay service is offered through the Yahoo Internet portal, MSN Music, MP3.Com and roxio.com.

Subscription services are particularly attractive to the music industry owing to their potential to draw "sleepers" - consumers who would buy more music if it were more readily available and easier to purchase. Surveys suggest that digital music distribution has led to consumers increasing the amount of time that they listen to music (National Association of Recording Merchandisers 23). Such findings support the notion that digital distribution could expand the market for music by making music easier to obtain. However, the success of subscription services turns on the issue of whether anyone will pay for music that can be obtained elsewhere for free. The music industry therefore recognizes that any legal business model adopted should be more attractive for consumers than those represented by peer-to-peer or broadcasting services. In this context, it is important to note that many consumers (justifiably) consider the mp3 files currently available on peer-to-peer services as audibly inferior to CDs. A survey conducted by the University of Southern California found that 51 percent of respondents characterized CDs as having excellent sound quality, whereas only 19 percent of $\mathrm{mp} 3$ users viewed mp3 files comparably (Latonero 13). Other researchers have discovered that consumers view guaranteed file quality and virus protection as important and desirable features of any subscription service (Jupiter Media Metrix 1). Hence, subscription services offering these attrations may be especially appealing to consumers.

A particular concern for MusicNet and pressplay is that the Big Five will have to cross-license their catalogs to build an attractive subscription system (EMI presently is the only label whose catalog will appear on both services). Consumers will find it much more convenient to go to a single site, rather than multiple sites, to access a wide variety of music. The antitrust attention that MusicNet and pressplay have drawn in both Europe and the United States impacts the legality of existing licensing agreements involving the Big Five. The central concern of these 
investigations "appears to be whether the record labels have worked together using exclusive copyright power over musical recordings to control the development of the digital marketplace" (Matthews and Wilke 3). The outcome of these investigations will have a substantial impact on the availability of the Big Five's catalogs for subscription services in general. Irrespective of the outcome of these investigations, consumer choice and willingness to pay more for the convenience of accessing a wide selection of music at individual Internet sites may drive labels to license their catalogs more widely.

\section{Pay-per-track or-album}

While experts predict that subscription service is the most likely business model for the industry, a number of other models hold promise as well. In addition to initiating subscription services, all five of the major labels have launched pay-per-download initiatives. EMI, BMG, and Sony now charge consumers to download songs and, in some cases, full-length albums. For example, Sony.com users can download singles for $\$ 1.99$.

The major labels also are licensing their music to third-party aggregators, who pool music from different labels. For instance, one of the online distributors for BMG is Lycos, an Internet portal. At Lycos, users can download BMG singles for between $\$ 1.98$ and $\$ 2.98$, and albums for between $\$ 6.98$ and \$15.98. Also, MTVi has agreements with all five major labels to sell digital downloads. MTVi is the umbrella company for MTV.com and VH1.com, as well as various other sites including country.com. At MTVi sites, listeners can pay per download prices of anywhere between 99 cents for a single to $\$ 18.98$ for an album.

Inevitably, a critical issue the Big Five face concerning pay per download services is pricing. The Gartner Group in an August 2000 survey found that consumers are probably no longer willing to purchase an entire CD for only one song (1). The Gartner Group also proposes that for labels to recoup the revenues that would result from the purchase of an entire CD, the companies will have to charge $\$ 5$ per track; however, this study indicates that consumers are willing to pay only between 99 cents and $\$ 1.99$ per track (1). This clearly points to a major drawback in the pay-per-track/album model. As Dolan observes, one of the needs of music consumers is "lower than CD prices for music if forced or motivated to pay for online access" (8). At present, the pricing of per-track and per-album sales is clearly influenced by comparisons with the prices of CD singles and albums. However, consumers realize that the costs associated with distributing music over the Internet are low compared with, for example, selling a CD in a traditional record store. May and Singer underscore this fact when they state that "nearly two-thirds [of the total delivered cost of a CD] comes from activities directly threatened by digital distribution over the Internet" (129). This reality will make the pricing of music on a per-track (or per-album) basis critical in making this model feasible. Yet, if the Big Five engage in this variant pricing, they risk upsetting their traditional sales channels-particularly music stores. Also, it is unlikely that the current online pricing structure for per-track and per-CD sales will be attractive to many consumers. Such a model may, however, enjoy a wider appeal if consumers gain access to products that bring with them perceptions of additional value-for example, gaining access to rare tracks or prerelease recordings. 
Notwithstanding these vagaries, one attraction of the pay-per-track or -album option for the music labels is that it potentially allows for pricing that takes into account the relative popularity of different artists and individual songs. As one record company executive states, "In a perfect world, you would charge more for a big hit than you will for the tenth track on a Rick Springfield record" ("Changing"). This inducement also applies to artists who may wish to distribute their music directly to consumers.

\section{Artist to consumer}

To gain some insight into why the artist-to-consumer model may be attractive for some musicians, consider the following description of the artist-record label relationship:

An artist typically receives an advance payment on any profit his product may produce. The artist's royalties from album sales are then redirected to the record company to pay back the advance. This is important because it is one of the reasons the recording industry is viewed as corporate entities that are concerned only with their profits. In practice, most artists make no money from record sales at all. They make a profit only by touring and merchandise sales. (Wendkos pt. 4)

The music companies, aided by global satellite television channels devoted primarily to music, exploit the economies of scale that result from promoting and marketing a few star performers who can satisfy the listening needs of larger audiences at lower costs. As a result, they neglect investments in new, unproven talent (Strobl and Tucker 115). By contrast, according to Lawrence Lessig, Professor of Law at Stanford University, the relatively low cost of distributing music via the Internet will lead to greater diversity (15).

Historically, the major labels have focused most of their efforts on established artists, relegating the nurturing of new artists to the smaller independent record labels (Black and Greer 14). This has led to fewer releases and a lack of innovation in the music industry as a whole. Black and Greer attribute this to industry concentration levels (the extent to which the major music labels dominate the industry, as measured by relative market share) (13). An earlier study by Peterson and Berger found that, over a 26-year period, lack of diversity in music forms was attributable to the oligopolistic nature of the music industry (170). This industry concentration has allowed relatively few artists to achieve commercial success. As Hirsch shows, artists who achieve commercial success are a subset of a larger field of contenders, many of whom are just as creative and talented as their commercially successful counterparts (644). Accordingly, many musicians today believe that digital music can democratize the music industry, lessening the control of the major labels, making more music available to consumers, and allowing a more equitable distribution of profits (Coats et al.). The electronic musician Moby comments that:

It used to be that you started a record company because you loved music. Now record companies are being bought... not out of love of music but to increase their market share and shareholder value. They start manufacturing the music that becomes a commodity-generic disposable pop music. (quoted in "Pot, Kettle" 13)

William Fisher notes that most of the retail price of a CD goes to the record company that produced the $\mathrm{CD}$, the manufacturer, the distributor, and the retailer; 
artists typically do not receive more than 16 percent (2). In light of this allocation, the artist-to-consumer approach may be financially attractive to some artists, who, though they may reach a smaller audience, can nonetheless make more money. Realistically, however, the artist-to-consumer model may hold out less promise in general since many artists measure their artistic success, at least in part, by the number of consumers who buy their work (Frith).

Todd Rundgren, a 1970s progressive rock musician with a loyal fan base, has become one of the first musicians to master the Internet as a means of fostering sales. Of his decision to do so, Rundgren has said that:

It occurred to me that with the aid of some modern advances, I could go directly to my audience, ask them if they would commit to buying the music, and then deliver it to them as it is produced, thus eliminating the middleman. (Salkever 2)

To gain access to music, live Webcasts, specialized merchandise, etc., on Rundgren's website (www.tr-i.com), fans pay a \$25 subscription fee. Other musicians, including Aimee Mann (www.aimeemann.com), offer albums and individual songs for downloading for a fee (Mann pt. 4).

Rundgren's site typifies artist-to-consumer sites that generally offer merchandise other than music and provide information about additional sources of revenue for artists, such as concert details. For example, Prince recently inaugurated the New Power Generation Music Club. This subscription-based service has either a basic (\$7.77 per month) or premium (\$100 per year) option. Basic members may download a minimum of three songs per month and an hour-long audio show. Premium members may also download a bonus track each month, buy advance concert tickets, buy from an exclusive retail section, and attend exclusive events.

The challenge facing these and other artists is reminiscent of that confronting the major music companies: how to make artists' websites more attractive than those containing pirated music. Sylva (241) proposes several options:

- Using sites that have the artist's domain name,

- Providing sites that are hosted by the artist,

- Offering real-time, online chats or special, live performances,

- Providing collaborative opportunities with an artist,

- Enabling registered users to access pre-released music, and

- Creating loyalty award programs and online communities.

Established artists like Rundgren and Prince stand a fairly good chance of successfully launching and maintaining the artist-to-consumer delivery of music and related products. New artists face the thorny problem of making fans aware of their music. As G. Robertson observes:

The issue remains that an artist has to be sold to the public and if the record companies are not doing it some other party will do so and it is unlikely to be the artist. The only possible exceptions here are acts who are already huge and have the brand awareness and money to support themselves. They may even help out new acts on the back of their success, but that is then just fulfilling the record company and it's all down to a question of personalities as far as a new act is concerned. The crossover between creative-artist management and record companies may well become considerable. (244)

As these comments indicate, the artist-to-consumer business model is not attractive to all musicians; it is most likely to be adopted by those who already 
have a significant, loyal fan base. Also, to those musicians who judge their success in terms of popularity rather than money, the marketing expertise of the Big Five will remain appealing, as it will to those who lack the expertise or the inclination to market their own music.

\section{Discussion}

Digital downloading is transforming the music business from a product to a service business (Garlick 3; Spellman 1). The recent stagnation of global music sales makes it unlikely that the industry can achieve future growth through existing business models that rely on the distribution of physical music products, predominantly CDs.

The development of (legal) business models for the distribution of music via the Internet has recently become more feasible as some of the issues associated with copyright in this complex environment have been resolved. Copyright rights associated with music can be categorized as recording rights, composition (mechanical) rights, and performance rights. As Chmielewski explains:

It all begins with a song-say, "I Will Always Love You." Arista Records owns the right to Whitney Houston's 1992 recording [the recording rights]. But country-music artist Dolly Parton wrote the words and music-and she gets the songwriting credits [composition rights].

For Arista to create a "greatest hits" album that includes this song, it must pay a licensing fee known as a "mechanical" for the right to duplicate it. That 7.55-cent fee is paid to the Harry Fox Agency, the collection agent for the National Music Publishers' Association. The NMPA distributes the money to its 27,000 publishers who, in turn, split the proceeds with songwriters like Parton.

Performance rights are different. Every time a radio station plays "I Will Always Love You," it pays a separate performance fee to a different publisher-in this case, BMI Music Publishing, the world's largest music publisher. It collects this royalty every time the song is performed in restaurants and dance clubs, concert halls or any other public place (1).

These rights have affected Internet music distribution in several ways. First, the major labels recently have licensed their catalogs to Internet sites, notably pressplay and MusicNet. Second, the National Music Publishers' Association (NMPA), the Harry Fox Agency, and the RIAA recently reached an agreement concerning mechanical license for works that will appear on pressplay, Musicnet, and other such sites. These licenses apply to subscription services for on-demand streaming and limited downloads-i.e., downloads that can be played only for a limited period of time or number of times. The logic behind the need to obtain mechanical rights for such services is that they in essence "amount to a replacement for the physical product on compact disc, cassette tape or LP. It's a duplication-and as such, songwriters and music publishers are entitled to a mechanical royalty" (Chmielewski 1).

An unresolved issue is whether website operators must obtain public performance licenses. There appears to be agreement that streaming constitutes public performance

because the musical work is delivered by means of a device or process to members of the public who are capable of receiving the transmission in separate 
places at different times. Although there is no compulsory license for the public performance of a musical work under the [Copyright] act, such licenses may generally be obtained from the copyright proprietor's PRO [Performance Rights Organization]. (Phillips and Cutler 1)

Experts disagree, however, as to whether downloads should be covered by performance licenses. For example, one of the major Performance Rights Organizations, BMI, argues that:

all transmissions, including downloads, are clearly public performances and should be compensated. The recommendation of the Copyright Office leaves open whether adequate compensation will take place and presents a substantial risk that songwriters, composers and music publishers may not be sufficiently protected. (BMI 1)

Aside from issues of copyright, the music industry will have to deal with heightened consumer interest in music distributed in the single, as opposed to album, format. The central music unit of consumer interest in the virtual music world is the single, not, as in the physical world, the album. A move toward distributing music in a virtual form will likely have significant impact on artist development and the cost structure of the music industry. For example, the task of "picking winners"-i.e., singles that will become successful-is even more critical online since consumers will have much more choice than they have at present, for example, in a Virgin Megastore. However, a movement toward a singles-based music market could have detrimental effects on artists under contract with record labels. These labels act, in essence, as venture capitalists-investing in many artists in the hope that a few will provide significant financial returns. The distribution of music online will potentially reduce costs or allow for costs to be distributed within the music industry:

Music conveyed over the Net doesn't require the pressing of CDs in large factories. In fact, record labels may transfer the system's few remaining manufacturing costs to store-based kiosks that press CDs on demand....

Music conveyed over the Net doesn't require physical distribution; instead, distribution involves just a few cents' worth of bandwidth. ...

Promotional dollars for music carried over the Internet will focus on tighter groups of consumers, not on untargeted displays in stores. Data collection over the Net will make it possible to conduct targeted prerelease research as never before. Record companies may spend more money per consumer, but they will spend it on fewer consumers....

The reduction in the number of CDs produced will mean that there will be fewer CD retailers, with their overhead, marketing, and inventory-carrying costs. (May and Singer 129-30)

Whatever the reductions in the above cost areas, the virtual distribution of music may profoundly affect artist development and financing. A greater focus on singles would appear to lead labels to invest in a wider range of artists, or at least focus their efforts on the development of single-, as opposed to album-, oriented artists. Technology can help them identify such artists. For example, Garageband.com has developed an interesting variation on the broadcasting model. Its users evaluate songs and are rewarded with a free CD for every 40 songs they review, based on predefined criteria. In performing what is in essence the role of a talent spotter: 
Garageband Records melds the ubiquitous and democratic nature of the Internet with the company's proprietary preference engine software, which filters, gauges, and quantifies fan interest level.... For the fan, the Garageband Records website and the company's All Access(TM) CD format offer a backstage pass. Importantly, the company allows the fan to be part of an intelligent process for determining which bands will be signed and which records will be released. Fans are encouraged to visit the site, submit reviews of songs, buy a favorite band's CDs, and become an integral part of a band's future success. (GarageBand)

In addition to reducing costs and refining existing business practices, new technology allows the release of music in new formats, which, some commentators note, have traditionally benefitted the music industry and led to price increases and increased sales (Garofalo 328). For instance, the advent of higherpriced and higher-quality CDs has prompted many consumers to replace music that they already own on audiocassette and vinylite. Indeed, the growth in the popularity of CDs indicates consumers' willingness to pay more for better-quality sound recordings and ease of access to favorite tracks (Strobl and Tucker 115). Online music promises not only to increase global music sales but also convenience to consumers. In particular, newly formulated business models could entice so-called "sleeper" music buyers-i.e., those attracted by the convenience of buying online (Ponce 68). Also, the potential availability of a wider selection of music could help increase the market size (Ponce 68).

However, to enjoy these benefits, the music industry must adopt new business models that create more attractive value propositions than those offered through piracy (Magex). Such models must provide a high-quality listening experience and ease of usage at an attractive price. In addition, the industry will need to offer a service that avoids the problems that affect those who download music for free, such as poor sound quality, virus infection, and legal threat. As to the latter, consumers are increasingly concerned about their own privacy when they download via peer-to-peer systems. New copyright technologies that identify copyright infringement are being developed. For example, Copyright.net has invented a software "robot" that seeks out and reports any illegal downloads. Copyright holders may then demand that the infringing parties' Internet Service Providers (ISPs) terminate their connections (Copyright.net). Only when the Big Five come up with forms of doing business that take into account such issues will they reclaim the dominance they once enjoyed.

Any new business model must also take into account the fact that the Internet may potentially provide an entertainment experience over and above listening to the music itself. One lesson the music industry should learn from the success of Napster is that consumers value a wide choice of music-typically, they are indifferent to the label from which that music comes (von Lohmann 44). This means that the major music labels need to be willing to license their products to thirdparty content aggregators. Unfortunately, it appears that the current subscription models will allow no aggregation of all the major labels. If consumers have to subscribe to several services, then the market for these services will be smaller. This lack of a definitive value proposition for consumers will likely add to the problems that already affect subscription services, such as high churn rates (existing members leaving and new members joining). Consumer loyalty to individual subscription services will be enhanced by subscription services that give consumers a wide choice of music. 
In addition to offering consumer choice, successful business models will incorporate music-related materials-video, lyrics, song sheets, interviews, and links to relevant websites (Magex). These other products in themselves provide significant opportunities for revenue growth. Furthermore, the Big Five can exploit to their advantage their back catalogs. By one estimate, sales of such catalog titles account for 40 percent of sales but more than 70 percent of profits (Singh 4). Internet-based business models could greatly increase the availability of these titles, while at the same time reducing the costs associated with their distribution. However, those who distribute music via the Internet will also need to cater to those consumers who like to own a physical product, complete with cover art, lyrics, and notes on the artist. Catering to such needs is especially critical given the availability of free music: If music labels can provide an experience over and above just listening to music, they are likely to find that customers are less price-sensitive when evaluating subscription or other service offerings (Magex).

In positioning themselves to exploit these opportunities for increasing sales, the major labels would do well to remember that individual consumers clearly place differing levels of importance on listening to and purchasing music. As Mizerski et al. observe, "the consumption of music appears to be more of an emotionally-based activity than many of the products traditionally addressed by marketing" (79). That individuals have various degrees of emotional attachment to music enables marketers to tailor product offerings and marketing efforts to individual consumers or distinct groups. Hence, one of the greatest attractions of online business models is that they allow for targeted advertising and one-to-one marketing (Bakos 71-72). Simply put, the provision of music with advertising can have a major impact on marketers who wish both to monitor the effectiveness of their advertisements and to target consumers more effectively. For example, consumers with high music involvement are more likely to be amenable to relationship marketing tactics (Gordon, McKeage, and Fox 443). Music labels and musicians can therefore potentially use the Internet to reduce their search costs-those expenses associated with identifying qualifying buyers of their products, such as market research and advertising (Bakos 70). In short, the Internet offers the opportunity for the music industry to better understand and meet the needs of consumers (Magex). As Thomas Dolby Robertson notes:

What the Web offers labels is a unique opportunity to understand for the first time, what really makes the public tick. Who they are, why they buy, what else they do when we're not buying CDs. There's never been a marketing platform quite like it. Armed with this information, a label ought to be able to precisely target the correct demographic for its artist, and cut out the wastage in its marketing budget. (2)

Apropos of Robertson's point, the Internet presently offers technologically advanced means of tracking the interests of website visitors, grouping people with common interests and selling ad space to those advertisers seeking to reach those people (Fox and Wrenn 114). The major labels could compile such groups by using neural networks to search for common threads in downloaded music or purchases made at the site, or through consumer-volunteered information. To illustrate, Amazon's Listmania permits consumers to establish wish lists of goods or services, favorite artists or music, videos, etc. and share their lists with other site visitors. Another Amazon service, Purchase Circles, logs the top purchases of aggregated users from various organizations. Both Listmania and Purchase Circles 
are affinity programs that help develop Internet communities of people with similar interests. Similarly, the successful creation of online communities will be critical to developing business models for the digital distribution of music. Such communities offer a sense of belonging to their members, thereby making consumers less likely to migrate to competing music services (Dayal, Landesberg, and Zeisser 47).

The Big Five have been slow to realize the potential of the Internet. This inertia is, perhaps, understandable given that viewing music as a service to be delivered via the Internet would necessitate a dramatic change in thinking and infrastructure. However, the potential for music as a service appears significant, if developed with well-conceived business models that provide value to consumers over and above that offered by free downloads. The challenge for the music industry is to ensure that it provides this value.

\section{Acknowledgments}

I appreciate the insightful comments of two anonymous reviewers. I also very much appreciate the comments made upon earlier drafts of this paper by Brenda Knowles and Fred Naffziger, Professors of Business Law, Indiana University South Bend.

\section{Notes}

1. For an excellent discussion of factors leading to concentration in the recording industry, refer to Alexander ("Entry Barriers" 86-87).

\section{Works cited}

Alexander, Peter. "Product Variety and Market Structure: A New Measure and a Simple Test." Journal of Economic Behavior and Organization 32 (1997): 207-14.

_ . "Entry Barriers, Release Behavior and Multi-Product Firms in the Music Recording Industry." Review of Industrial Organization 9 (1994): 85-98.

BMI. "BMI Releases Statement in Response to Copyright Office Report on DMCA." Recent News 30 Aug. 2001. BMI. 1 Nov. 2001 <http://www.bmi.com/news/index.asp>.

Bakos, Yannis. "The Emerging Landscape for Retail E-commerce." Journal of Economic Perspectives 15.1 (2001): 69-80.

Black, Michael, and Douglas Greer. "Concentration and Non-Price Competition in the Recording Industry." Review of Industrial Organization 3 (1987): 13-37.

Brull, Steven V. "A Rock ' $n$ ' Roll Vet takes to Cyberspace to Challenge the Music Industry." Business Week 12 Feb. 1999: 15 pars. Business Week. 1 Nov. 2001 <http:// www.businessweek.com>.

Burke, Andrew E. "How Effective Are International Copyright Conventions in the Music Industry?" Journal of Cultural Economics 20 (1996): 51-66.

Carton, Sean. "Will the Digital Music Industry Survive?" 27 Sept. 2000: 18 pars. Clickz. 1 Nov. $2001<$ http://www.clickz.com>.

Cartwright, Shawn D. "Napster: A Business in Search of a Viable Model." Journal of Business Strategy 21(5) (2000): 28-32.

"Changing the Way you Pay for Music?" PCWorld 25 Oct. $2000<$ http://www. pcworld.com>.

Chmielewski, Dawn C. "Record Labels, Music Publishers in Online Dispute." San Jose Mercury News 23 Aug. 2001: 22 pars. Mercury News. 1 Aug. 2001 <http://www. mercurynews.com>. 
Coats, William S., Vickie L. Freeman, John G. Given, and Heather D. Rafter. "Streaming into the Future: Music and Video Online." Loyola of Los Angeles Entertainment Law Journal 20 (2000): 285-307.

Copyright.net. "Copyright.net Introduces CopyrightAgent." <http://www. copyright.net/ copyrightnet/press.cfm\#>. Accessed 20 Dec. 2001.

Cyber Dialogue. "Cybercitizen Entertainment Continuous Advisory Service." CyberBits Trends Report 1 (2000): 1.

Dayal, Sandeep, Helene Landesberg, and Michael Zeisser. "Building Digital Brands." McKinsey Quarterly 2 (2000): 42-51.

Diebold Group. "Wanted: A Survival Plan for the Music Industry-Chapter One: Problem Areas of the Recording Industry." Music Dish 21 Jan. 2001: 12 pars. Music Dish. 1 Nov. $2001<$ http://www.musicdish.com>.

- Wanted: A Survival Plan for the Music Industry-Napster and the Consequences. Frankfurt: Diebold, 2001.

“Dig That Digital Music." Business Week. 30 Apr. 1999: 1. 1 Nov. 2001 <http://www. businessweek.com>.

Dolan, Daniel P. “The Big Bumpy Shift: Digital Music via Mobile Internet." First Monday 5.12 (2000): 11 pp. First Monday. 1 Nov 2001 <http://www.firstmonday.dk/issues/ issue5_12/dolan/index.html>.

Emusic. "Annual Report." 1999. Emusic. 1 Nov. $2001<$ http://www.emusic.com>.

EverAd. "About EverAd-Technology." 2001. EverAd. 1 Nov. $2001<$ http://www.everad. com/technology.html>.

Fisher, William. "Digital Music: Problems and Possibilities." Harvard Law School 10 Oct. 2000. Harvard University. 1 Nov. 2001 <http://www.law.harvard.edu/academic_affairs/ coursepages/tfisher/music.html>.

Foege, Alec. "Free Music and the Death of the Album." Spin 5 Aug. 2000: 159-62.

Fox, Mark A., and Bruce Wrenn. "A Broadcasting Model for the Music Industry." International Journal of Media Management 3 (2001): 112-19.

Freund, Jesse. "Garage Bands Go Global." Wired 5.2 (1997): 5 pars. Wired. 1 Nov. 2001 <http://www.wired.com/wired/archive/5.02/beta.html>.

Frith, Simon. The Sociology of Rock. London: Constable, 1978.

GarageBand. "Company Info." <http://www.garageband.com>. Accessed 20 Dec. 2001.

Garlick, Mia. "Pricing Recorded Music in an Online World." Gilbert \& Tobin 14 July 2000. Gilbert \& Tobin. 1 May 2001 <http://www.gtlaw.com.au/pubs pricingrecordedmusic.html>.

Garofalo, Reebee. "From Music Publishing to MP3: Music and Industry in the Twentieth Century." American Music 17 (1999): 318-53.

Gartner Group. "Gartner Says Record Industry Must Implement Digital Distribution Model to Support Single-Track Purchases." Music Industry News Network 20 Aug. 2000: 5 pars. Music Industry News Network. 1 Nov. 2001 <http://www.mi2n.com>.

Gerbert, Phillip A. "Music-The Prototype for the Digital Economy." Highlights from the Digital Marketplace 1 (2000): 13 pp. McKenna Group. 1 May $2001<$ http://www.mckennagroup.com/publications/Highlights_1.pdf>.

Glynn, Simon. "Making Money From Free Services." Mercer Management Consulting. 1999. Mercer Management Consulting. 1 Nov. 2001 <http://www.mercermc.com>.

Gordon, Mary Ellen, Kim McKeage, and Mark A. Fox. "Relationship Marketing Effectiveness: The Role of Involvement." Psychology and Marketing 15 (1998): 443-59.

Graziano, Mike, and Lee Rainie. "The Music Downloading Deluge." Pew Internet \& American Life Project 24 Apr. 2001: 8 pp. Pew Internet. 1 Nov. $2001<$ http://www. pewinternet.org/reports>.

Haring, Bruce. Beyond the Charts: MP3 and the Digital Music Revolution. Los Angeles: OTC Books, 2000. 
Hill, Rebecca J. "Pirates of the 21st Century: The Threat and Promise of Digital Audio Technology on the Internet." Santa Clara Computer and High Technology Law Journal 16 (2000): 311-43.

Hirsch, Paul M. "Processing Fads and Fashions: An Organization-Set Analysis of Cultural Industry Systems." American Journal of Sociology 77 (1972): 639-59.

$\mathrm{Hu}$, Jim. "Net Music Fans Would Pay for Albums, Study Says." 7 June 2000: 12 pars. 1 Nov. $2001<$ http://.cnet.news.com>.

International Federation of the Phonograph Industry. "Recording Industry World Sales 2000." IFPI. <http://www.ifpi.org/statistics/worldsales.html>. Accessed 20 Feb. 2002.

—_. "2001 IFPI Music Piracy Report." 2001. IFPI. <http://www.ifpi.org/site-content/ antipiracy/piracy2001.html>.

Jupiter Media Metrix. “Jupiter: US Online Music Market to Reach \$5.4 billion in 2005, Led By Industry Shift to Digital Subscriptions." 2000. 1 May $2001<$ http://news.excite.com>.

Latonero, Mark. "Survey of MP3 Usage: Report on a University Consumption Community." Norman Lear Center. June 2000. Annenberg School of Communication, University of California. 1 Nov. 2001 <http://entertainment.usc.edu/publications/mp3.pdf>.

Lee, Hane C. "How MusicNet Heats Up the Digital-Music War." The Standard 3 Apr. 2000. 1 May $2001<$ http://www.thestandard.com>.

Lenhart, Amanda, and Susannah Fox. "Downloading Free Music: Internet Music Lovers Don't Think It's Stealing." Pew Internet \& American Life Project 28 Sept. 2000: 13 pp. Pew Internet. 1 Nov. 2001 <http://www.pewinternet.org/reports/pdfs/ PIP_Online_Music_Report2.pdf>.

Lessig, Lawrence. “Expert Report of Professor Lawrence Lessig." Napster June 2000. Napster. 1 Nov. 2001 <http://www.napster.com/pressroom/legal.html>.

Leyshon, Andrew. "Time-Space (and Digital) Compression: Software Formats, Musical Networks, and the Reorganization of the Music Industry." Environment and Planning A 33 (2001): 49-77.

Lovering, John. "The Global Music Industry: Contradictions in the Commodification of the Sublime." The Place of Music. Ed. Andrew Leyshon, David Matles, and George Revill. New York: Guildford Ps, 1998. 31-56.

Magex. "Online Music Piracy, 'I Fought the Law and the Law...'." Magex 2000. 1 Feb. 2001 $<$ http://www.magex.co.uk>.

Mann, Charles C. "The Heavenly Dukebox." Atlantic Monthly Sept. 2000: 4 pts. The Atlantic. 1 Nov. 2001 <http://www.theatlantic.com/issues/2000/09/mann.htm>.

Matthews, Anna W., and J. R. Wilke. "Probe of Competitive Practices, Licensing of Online Music Business Is Expanded." Wall Street Journal 15 Oct. 2001: 3.

May, Brett, and Marc Singer. "Unchained Melody." McKinsey Quarterly 1 (2001): 128-37.

Mintzberg, Henry. The Rise and Fall of Strategic Planning. New York: Free Press, 1994.

Mizerski, Richard, Marya J. Pucely, Pamela Perrewe, and Lori Baldwin. "An Experimental Evaluation of Music Involvement Measures and Their Relationship with Consumer Purchasing Behavior." Popular Music and Society 12 (1988): 79-96.

MP3 Impact. "Special Analysis: Quarterly Report." MP3 Impact: The Digital Music Weekly 13 Apr. 1999: 1.

MusicNet. "MusicNet Launches Today on RealOne Music." 4 Dec. 2002 <http:// www.musicnet.com/press.html>.

National Association of Recording Merchandisers. "Creating Industry Value from Digital Music Distribution." National Association of Recording Merchandisers. Sept. $2000<$ http:// www.narm.com/programs/research>. Accessed 20 Feb. 2002.

Newton, Jon. "To Watermark, or Not to Watermark-That Is the Question." MusicDish 21 May 2000: 31 pars. MusicDish. 1 Nov. 2001 <http://www.musicdish.com>.

Peterson, Richard A., and David G. Berger. "Cycles in Symbol Production: The Case of Popular Music." American Sociological Review 40 (1975): 158-73. 
Pfahl, Michael. "Giving Away Music to Make Money: Independent Musicians on the Internet." First Monday 6.8 (2001): 15. First Monday. 1 Nov. 2001 <http:// www.firstmonday.dk/issues/issue6_8/pfahl/index.html>.

Phillips, Bruce H., and David M. Cutler. "Performance and Distribution Issues; Obtaining Internet Music Licenses for Digital Downloads and Streaming." Entertainment Law and Finance 16.4 (2000): 1.

Ponce, B. "The Impact of MP3 and the Future of Digital Entertainment Products." IEEE Communications Magazine 37.9 (1999): 68-70.

"Pot, Kettle?" Mojo Jan. 2001: 13.

Recording Industry Association of America. "The Cost of a CD." <http://www.riaa.com/ new/marketingdata/cost.asp >. Accessed 25 Mar. 2004.

—_. "Recording Industry Announces 2001 Mid-Year Shipments." 2001. 1 Nov. 2001 $<$ http://riaa.org/News_Story.cfm?id=446>.

—_. "The Recording Industry Association of America's 2000 Consumer Profile." <http:/ /riaa.org/PDF/2000_consumer_profile3.pdf>.

_. "Recording Industry Releases 2000 Manufacturers' Shipments and Value Report." 2000. 1 Nov. 2001 <http://riaa.org/MD-Tracking.cfm>.

Robertson, G. "Music, the Internet and the Role of Collection Societies." Entertainment Law Review 7 (1994): 242-46.

Robertson, Thomas Dolby. "The Upside of Music on the Web-Part Two." Recording Industry Association of America. <http://www.riaa.com/news/guestcolumns/ thomasdolby_part2.asp>. Accessed 25 Mar. 2004.

Rothenbuhler, Eric W., and John W. Dimmick. "Popular Music: Concentration and Diversity in the Industry, 1974-1980." Journal of Communication 32.1 (1982): 143-49.

Rothernberg, Randall. "Rob Glaser, Moving Target." Wired 7.8 (1999): 6 pp. Wired. 1 Nov. 2001 <http://www.wired.com/wired/archive/7.08/glaser_pr.html>.

Sadler, David. "The Global Music Business as an Information Industry: Reinterpreting Economics of Culture." Environment and Planning A 29 (1997): 1919-36.

Salkever, Alex. "Upbeat at Napster-and the Growing New-Media Music Crowd." Business Week 23 June 2000: 18 pars. Business Week. 1 Nov. 2001 <http://www.businessweek.com>.

Selby, John. "The Legal and Economic Implications of the Digital Distribution of MusicPart One." Entertainment Law Review 11.1 (2000): 4-10.

Sherman, Cary. "Music on the Internet: A New World Is Waiting." The Brookings Review 19.1 (2001): 35-37.

Singh, Ashish. "Cutting Through the Digital Fog." Bain Strategy Brief 15 Aug. 2001. Bain \& Co. 1 Nov. 2001 <http://www.bain.com/bainweb/about/insights/pract_insights.asp>.

Spellman, Peter. “The People Have Clicked (Er, Spoken)-Musings on 'A Survival Plan for the Music Industry'." Music Dish 22 Feb. 2001: 27 pars. Music Dish. 1 Nov. 2001 <http://www.musicdish.com/mag/print.php3>.

Strobl, Eric A., and Clive Tucker. "The Dynamics of Chart Success in the U.K. Pre-Recorded Popular Music Industry." Journal of Cultural Economics 24 (2000): 113-24.

Sylva, Jennifer B. "Recent Trends in Copyright Law: Relevant Technologies and Emerging Business Models." Loyola of Los Angeles Entertainment Law Journal 20 (2000): 217-41.

von Lohmann, Fred. "After Napster." California Lawyer Jan. 2001: 42-45.

Wendkos, Eli. "Digital Music and New Media: Legal Issues vs. Business Practices." 12 Aug. 2001: 13 pts. Music Dish. 1 Nov. 2001 <http://www.musicdish.com/mag/?id=4240>.

Mark Fox is Professor of Management and Entrepreneurship at Indiana University South Bend. His research interests include theories of superstardom as applied to the music industry, the impact of artists' death on music sales, music industry business models, and the contributions to musicians' success while touring. His web-page is at http://www.iusb.edu/ $\sim \operatorname{mfox} 1$ 